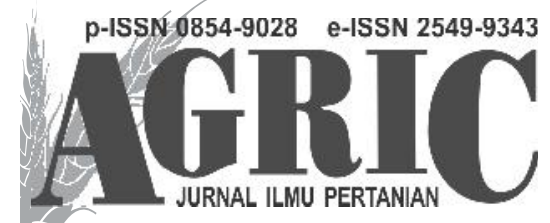

Fakultas Pertanian dan Bisnis Universitas Kristen Satya Wacana Jl. Diponegoro 52-60 SALATIGA 50711 - Telp. 0298-321212 ext 354 email: agric_fpb@yahoo.co.id, website: ejournal.uksw.edu/agric

\title{
PENGARUH ORIENTASI PASAR TERHADAP PENANGANAN PASCA PANEN BUNGA POTONG KRISAN DI DESA KENTENG, KECAMATAN BANDUNGAN, KABUPATEN SEMARANG
}

\section{THE EFFECT OF MARKET ORIENTATION TOWARDS POST-HARVEST HANDLING OF CHRYSANT CUT FLOWERS IN KENTENG VILLAGE, BANDUNGAN SUB-DISTRICT, SEMARANG}

\author{
Damara Dinda Nirmalasari Zebua \\ Program Studi Agribisnis Fakultas Pertanian dan Bisnis \\ Universitas Kristen Satya Wacana \\ damaradinda3@gmail.com \\ Sony Heru Priyanto \\ Program Studi Agribisnis Fakultas Pertanian dan Bisnis \\ Universitas Kristen Satya Wacana \\ sony.priyanto@staff.uksw.edu
}

Diterima 5 Juli 2017, disetujui 14 Juli 2017

\begin{abstract}
Chrysanthemum in Kenteng Village was conducted at Kenteng Village, Bandungan District, Semarang Regency on 12 February 2016-13 April 2016. This study aims to 1) determine the condition of the chrysanthemum farmers' market orientation; 2) know the determinants of market orientation of chrysanthemum businessman; and 3) the effect of market orientation on postharvest handling of chrysanthemum. In this study, 100 respondents were choosen to fill in questionnaire which is then analyzed using descriptive statistics and test SEM through IBM AMOS v.22 program. The results show that 1) the orientation on the customer to produce a quality cut flower chrysanthemum is the orientation of the most widely adopted by farmers. Farmers also take the positive things that other farmers do to repair the cut flower chrysanthemum produces, farmers give bonuses to regular customers who buy in large quantities and serve payment in cash receipt, and prioritize what the customer wants and needs and trying to fulfill compared to prioritize short-term profitability; 2) the three determining factors namely age, education and gender, gender can only be accepted as a determinant factor of market orientation. Ownership of market orientation by farmers comes from the demands of the market (brokers, traders and florist) and consumers (decorater); and 3) market orientation has positive influence on post-harvest handling of cut flower chrysanthemum, where the demands of customers on a good cut flower chrysanthemum, attractive, has a shelf life and optimum freshness make farmers give more attention to post-harvest activities.
\end{abstract}

Keywords: Market Orientation, Post-Harvest, Kenteng village, Chrysanthemum 


\begin{abstract}
ABSTRAK
Penelitian dilaksanakan di Desa Kenteng, Kecamatan Bandungan, Kabupaten Semarang pada tanggal 12 Februari 2016-13 April 2016. Tujuan penelitian ini adalah 1) mengetahui kondisi orientasi pasar pengusaha bunga potong krisan; 2) mengetahui faktor determinan orientasi pasar pengusaha bunga potong krisan; dan 3) mengetahui pengaruh orientasi pasar terhadap penanganan pasca panen bunga potong krisan. Dalam penelitian ini, diambil 100 responden dengan menggunakan kuesioner yang kemudian dianalisis dengan uji statistik deskriptif dan uji SEM melalui program IBM AMOS v.22. Hasilnya menunjukkan bahwa 1) orientasi pada pelanggan untuk menghasilkan bunga potong krisan yang berkualitas menjadi orientasi yang paling banyak diterapkan oleh petani. Petani juga mengambil hal-hal positif yang dilakukan petani lain untuk memperbaiki bunga potong krisan yang dihasilkannya, petani memberi bonus kepada pelanggan tetap yang membeli dalam jumlah banyak dan melayani pembayaran secara kasbon serta mengutamakan apa yang menjadi keinginan dan kebutuhan pelanggan dan berusaha memenuhinya dibandingkan dengan mengutamakan profitabilitas jangka pendeknya; 2) dari tiga faktor determinan yaitu usia, pendidikan dan jenis kelamin, hanya jenis kelamin yang dapat diterima sebagai faktor determinan orientasi pasar. Kepemilikan orientasi pasar oleh petani berasal dari tuntutan pasar (tengkulak, pedagang dan florist) dan konsumen (pendekor); dan 3) orientasi pasar berpengaruh positif terhadap penanganan pasca panen bunga potong krisan, dimana adanya tuntutan pelanggan terhadap bunga potong krisan yang baik, menarik, memiliki umur simpan dan kesegaran yang optimal membuat petani lebih memperhatikan kegiatan pasca panen.
\end{abstract}

\title{
Kata kunci: Orientasi Pasar, Pasca Panen, Desa Kenteng, Krisan
}

\section{PENDAHULUAN}

Indonesia merupakan negara beriklim tropis yang memiliki potensi untuk mengusahakan dan mengembangkan berbagai jenis tanaman hortikultura. Salah satu tanaman hortikultura yang sedang marak digemari oleh masyarakat adalah tanaman hias bunga potong krisan (Rukmana \& Mulyana, 1997).

Bunga potong krisan merupakan salah satu tanaman hortikultura yang mempunyai prospek cerah untuk dikembangkan seiring dengan meningkatnya permintaan konsumen akan bunga potong ini. Penambahan jumlah permintaan yang terus meningkat ini sebaiknya diikuti dengan pengembangan sistem penanganan pasca panen sehingga dihasilkan bunga potong dengan standar mutu yang dapat dipahami dan dijadikan pegangan oleh produsen dan konsumen (Arisanti \&Setiari, 2012). Penanganan pasca panen merupakan bagian dari SOP (Standard Operational Procedure) yaitu rangkaian kegiatan yang memberikan perlakuan terhadap bunga setelah panen sampai bunga itu diterima oleh konsumen (Fernando, 2015).

Pentingnya menjaga kesegaran bunga potong krisan sampai di tangan konsumen melalui perlakuan dalam penanganan panen dan pasca panen hendaknya menjadi perhatian setiap pengusaha agar produknya dapat diterima dengan baik olehkonsumen. Menurut Hutchinson et al (2003) dalam Riyanto (2010), untuk memberikan kepuasan konsumen dan memenuhi permintaan pasar salah satu usaha yang dapat dilakukan yaitu dengan meningkatkan hasil panen dan tetap mempertahankan kualitasnya.

Desa Kenteng adalah salah satu desa yang menjadi sentral budidaya bunga potong krisan di Kecamatan Bandungan, Kabupaten Semarang, Jawa Tengah (Kementerian Pertanian, 2014). Berdasarkan penelitian pendahuluan yang telah dilakukan, fenomena yang terjadi di desa ini yaitu sebagian besar 
petani telah melakukan penanganan pasca panen yang meliputi sortasi (sorting), pengkelasan (grading), dan pembungkusan (packaging). Petani bunga potong krisan melakukan penanganan pasca panen ini dikarenakan harga jual yang diterima akan lebih besar dibandingkan dengan menjual langsung produk tanpa melalui penanganan pasca panen. Dalam melakukan penanganan pasca panen ini, petani tetap memperhatikan keinginan dan kebutuhan konsumen sehingga produk yang dijual dapat diterima baik oleh konsumen. Kemampuan perusahaan atau perorangan untuk memahami dan memenuhi keinginan serta kebutuhan pelanggan inilah yang dikenal dengan istilah orientasi pada pasar atau market orientation (Narver \& Slater, 1990).Orientasi pasar sebagai konstruk tunggal menurut Narver \& Slater (1990) menekankan pada 4 hal yaitu: 1) orientasi pada pelanggan; 2) orientasi pada pesaing; 3) orientasi pada fokus jangka panjang dan 4) orientasi pada profitabilitas.

Perusahaan yang berorientasi pada pelanggan senantiasa berupaya menggali apa yang dapat disediakan perusahaan dengan membuat barang atau jasa yang terbaik (Wahyudiono, 2013 dalam Purwasari \& Suprapto2014). Orientasi pesaing berarti pemahaman yang dimiliki pengusaha dalam memahami kekuatan-kekuatan jangka pendek, kelemahan-kelemahan, kapabilitas-kapabilitas dan strategi-strategi jangka panjang baik dari segi pesaing utamanya saat ini maupun pesaing-pesaing potensial utama (Zhou et al., 2005 dalam Purwasari \& Suprapto, 2014). Orientasi fokus jangka panjang adalah perusahaan harus berusaha untuk menciptakan hubungan dengan pelangganjangka panjang secara menguntungkan. Orientasi profitabilitas adalah segala sesuatu yang dilakukan oleh perusahaan untuk memuaskan pelanggan, harus kembali ke tujuan utama yaitu profitabilitas (Narver \& Slater, 1990 dalam Priyanto, 2005).
Jaworski \& Kohli (1993) mengatakan orientasi pasar berhubungan dengan karakteristik individu petani yang meliputi usia, pendidikan dan jenis kelamin. Usia mempengaruhi daya kreativitas seseorang, karena biasanya semakin tua umur seseorang, maka akan semakin matang daya kreativitasnya. Pendidikan formal merupakan salah satu cara yang ditempuh untuk memperoleh pengetahuan dan menunjang kemampuan seseorang dalam hal pengaplikasian teknologi. Namun, pendidikan formal saja tidak cukup untuk meningkatkan pengetahuan, diperlukan penambahan informasi melalui kursus atau pelatihan yang lebih menekankan pada skill dalam mengelola suatu usaha yang dijalankan (Darmasetiawan \& Wicaksono, 2012). Menurut Powell \& Ansic (1997) dalamMunoz \& Saran (2012), berdasarkan jenis kelamin, perbedaan antara laki-laki dan perempuan dapat dilihat dari strategi usaha dan tingkah laku. Beberapa studi empiris melaporkan bahwa perempuan dan laki-laki berbeda dalam orientasi terhadap relasi (Riger \& Gilliga, 1980 dalamDavis et al., 2010). Perempuan lebih peduli pada hubungan antar pribadi dengan pelanggan dibandingkan laki-laki (Cartwright \& Gale, 1995 dalamDavis et al., 2010). Perempuan menunjukkan perhatian yang lebih besar dalam menjalin relasi dari aspek pemasaran dan penjualan. Hal ini dapat bermanfaat untuk mengembangkan orientasi pasar (Narver \& Slater, 1990 dalamDavis et al., 2010).

Penelitian ini bertujuan untuk 1) mengetahui kondisi orientasi pasar pengusaha bunga potong krisan; 2) mengetahui faktor determinan orientasi pasar pengusaha bunga potong krisan; dan 3 ) mengetahui pengaruh orientasi pasar terhadap penanganan pasca panen bunga potong krisan. 


\section{METODE}

Penelitian dilaksanakan pada 12 Februari 2016 hingga13April 2016diDesa Kenteng, Kecamatan Bandungan, Kabupaten Semarang. Pemilihan lokasi dilakukan secara sengaja (purposive) dengan pertimbangan bahwa Desa Kenteng merupakan salah satu sentral budidaya bunga potong krisan. Dalam penelitian ini, petani bunga potong krisan yang menjadi sampel. Pengambilan sampel dilakukan dengan teknik purposive sampling. Teknik purposive sampling adalah cara penarikan sampel yang dilakukan dengan memilih responden sesuai dengan kriteria yang telah ditentukan oleh peneliti (Bungin, 2011). Kriterianya yaitu petani bunga potong krisan yang membudidayakan sendiri bunga krisannya dan yang melakukan penanganan pasca panen. Berdasarkan Structural Equation Modeling (SEM), jumlah sampel yang dibutuhkan adalah 5-10 kali jumlah indikator yang digunakan, sehingga pada penelitian ini, jumlah sampel yang digunakan ada 100 responden (Sarjono \& Julianita, 2015).

Data yang digunakan untuk dapat menjawab tujuan dari penelitian ini adalah dengan mengumpulkan data primer dan data sekunder. Data primer dalam penelitian ini yaitu wawancara langsung di lapangan dengan berpedoman pada instrumen penelitian menggunakan kuesioner, sedangkan data sekunder diperoleh dari laporan, publikasi dan literatur yang relevan dengan penelitian. Pengisian kuesioner dilakukan dengan teknik wawancara langsung kepada responden. Data yang diperoleh kemudian dianalisis dengan statistik deskriptif dan model persamaan struktural (Structural Equation Modeling) yang dioperasikan melalui program IBM AMOS v.22.

\section{HASIL DAN PEMBAHASAN}

\section{Gambaran Umum Responden}

Responden di Desa Kenteng berasal dari tiga dusun yang berbeda, diantaranya Dusun Jurang, Dusun Kenteng dan Dusun Karanglo. Responden memiliki usia yang sangat heterogen. Agar lebih mudah melihat gambaran usia responden, maka peneliti akan menjabarkannya ke dalam Tabel 1 berikut,

Tabel 1 Usia Responden

\begin{tabular}{ccc}
\hline $\begin{array}{c}\text { Usia } \\
\text { (th) }\end{array}$ & $\begin{array}{c}\text { Jumlah } \\
\text { responden } \\
\text { (orang) }\end{array}$ & $\begin{array}{c}\text { Persentase } \\
(\%)\end{array}$ \\
\hline $\begin{array}{c}24- \\
39\end{array}$ & 23 & 23 \\
$40-$ & 63 & 63 \\
55 & & 13 \\
$56-$ & 13 & 1 \\
71 & 1 & 100 \\
$72-$ & 100 & \\
87 & & \\
\hline Total & 100
\end{tabular}

Pada umumnya, responden telah berusia 40 tahun ke atas dan didominasi oleh laki-laki. Mereka memilih menjadi petani dikarenakan tidak punya alternatif lain untuk bekerja, sementara petani yang berusia di bawah 40 tahun, beberapa diantaranya memiliki pekerjaan sampingan yaitu sebagai kuli bangunan. Hal ini dilakukan untuk memperoleh pendapatan tambahan dan berjaga-jaga jika ada kebutuhan mendesak yang harus segera dipenuhi seperti membayar biaya sekolah anak-anaknya.

Tabel 2 Pendidikan Terakhir Responden

\begin{tabular}{ccc}
\hline $\begin{array}{c}\text { Tingkat } \\
\text { Pendidikan }\end{array}$ & Jumlah & $\begin{array}{c}\text { Persentase } \\
(\%)\end{array}$ \\
\hline SD & 66 & 66 \\
SMP & 18 & 18 \\
SMA & 14 & 14 \\
D1 & 1 & 1 \\
S1 & 1 & 1 \\
\hline Total & 100 & 100 \\
\hline
\end{tabular}

Sumber: Analisis Data Primer, 2016 
Dalam banyak kasus, tingkat pendidikan ini sangat mempengaruhi stock of knowledge seseorang sehingga mampu menggerakkan inovasi usaha. Pendidikan yang sesuai dengan bidang yang digelutinya merupakan dasar yang sangat baik untuk pengembangan usahanya (Hisrich \& Peters, 1992 dalam Priyanto 2005). Namun yang perlu diingat adalah tingkat pendidikan tidak selamanya linier dengan kemampuan seseorang karena juga sangat tergantung proses pembelajaran yang terjadi pada saat memperoleh pendidikan tersebut.

\section{Kondisi Orientasi Pasar Petani Bunga Potong Krisan}

Tabel 3 Hasil Statistik Deskriptif

\begin{tabular}{lccccc}
\multicolumn{5}{c}{ Descriptive Statistics } \\
\hline & N & Minimum & Maximum & Mean & $\begin{array}{c}\text { Std. } \\
\text { Deviation }\end{array}$ \\
\hline Usia & 100 & 24 & 77 & 45.27 & 9.331 \\
Nilai OrPel & 100 & 2 & 5 & 3.61 & .584 \\
Nilai OrPes & 100 & 1 & 4 & 3.29 & .795 \\
Nilai OrFok & 100 & 1 & 4 & 2.32 & .909 \\
Nilai OrPro & 100 & 2 & 4 & 3.06 & .565 \\
Nilai Total OP & 100 & 9 & 17 & 13.31 & 1.733 \\
Nilai Sort & 100 & 1 & 3 & 1.53 & .577 \\
Nilai Peng & 100 & 2 & 4 & 2.82 & .500 \\
Nilai Pemb & 100 & 1 & 3 & 2.06 & .664 \\
Nilai Total PP & 100 & 5 & 10 & 6.96 & 1.399 \\
\hline Valid N (listwise) & 100 & & & &
\end{tabular}

Ket: OrPel $=$ Orientasi pelanggan, OrPes = Orientasi Pesaing, OrFok $=$ Orientasi Fokus Jangka Panjang, OrPro = Orientasi Profitabilitas, Sort $=$ Sortasi, Peng = Pengkelasan, Pemb $=$ Pembungkusan Sumber: Analisis Data Primer, 2016

Berdasarkan hasil di atas, dilihat dari nilai rataratanya (mean), dari keempat konstruk orientasi pasar yaitu orientasi pelanggan, orientasi pesaing, orientasi fokus jangka panjang dan orientasi profitabilitas, orientasi pelangganlah yang memiliki nilai rata-rata tertinggi yaitu 3,61 , diikuti dengan orientasi pesaing, orientasi profitabilitas dan orientasi fokus jangka panjang berturut-turut dengan nilai rata-rata 3,29, 3,06 dan 2,32. Hal ini berarti, dari keempat konstruk orientasi pasar, orientasi pelanggan menjadi orientasi yang paling banyak diterapkan oleh petani bunga potong krisan di Desa Kenteng dalam menjalankan orientasi pasarnya.
Dalam memenuhi kebutuhan pelanggan, banyak hal yang menjadi pertimbangan setiap petani terutama saat menentukan varietas krisan yang akan ditanam. Misalnya saat jelang lebaran seperti ini, beberapa bulan sebelumnya, petani akan memilih bertanam krisan yang warnawarni karena kebiasaan dari tahun ke tahun dimana saat lebaran tiba, banyak pelanggan yang mencari krisan dengan berbagai warna untuk digunakan diberbagai acara. Petani selalu berupaya agar bunga yang dihasilkan memiliki panjang tangkai mencapai $70-100 \mathrm{~cm}$ dan kelopak bunganya bagus serta tidak terserang penyakit, yang kemudian akan dijual sebagai grade A. Menurut Rukmana \& Mulyana (1997), upaya ini dilakukan untuk memenuhi permintaan pelanggan khususnya konsumen kelas I (hotel dan florist besar). Jika mereka menghasilkan grade B yang panjang tangkainya kurang dari $70 \mathrm{~cm}$ dan kualitas bunganya lebih rendah dari grade $\mathrm{A}$, maka mereka juga tidak khawatir karena akan ada tengkulak atau pedagang yang akan membeli dagangan mereka yang kemudian akan dijual lagi kepada florist menengah dan pendekor. Ini juga sesuai dengan pendapat Rukmana \& Mulyana (1997) yang mengatakan bahwa konsumen kelas II dan III seperti rumah tangga, florist menengah dan dekorasi massal menyukai krisan dengan panjang tangkai kurang dari $70 \mathrm{~cm}$. Dalam bertanam krisan, petani sama sekali tidak menganggap petani lainnya sebagai saingan. Mereka menganggap petani lain sebagai rekan kerja yang dapat mereka ajak bertukar pikiran dan berbagi informasi terutama dalam hal budidaya hingga pasca panen bunga potong krisan. Meski begitu, setiap petani akan selalu bersaing dalam hal kualitas dan kuantitas seperti menghasilkan bunga potong krisan dengan tangkai yang panjangnya lebih dari $70 \mathrm{~cm}$, kelopak bunga yang sehat dan tidak terserang penyakit dalam jumlah banyak dengan harapan hasil panennya dapat terjual lebih cepat di pasar. 
Menariknya, beberapa petani yang berani mengambil risiko besar, akan mengambil kesempatan untuk menanam varietas yang belum banyak dibudidayakan oleh petani lain dengan harapan saat waktu panen tiba, hasil panennya akan laku terjual di pasar dan harga jualnya menguntungkan.

Sebagian besar petani biasanya akan menitipkan dagangannya kepada tengkulak yang ada di desa tersebut. Hal ini dilakukan untuk meminimalisir kerugian saat harga krisan sedang memburuk. Di sisi lain, ada beberapa petani yang sudah memiliki langganan tetap seperti pendekor dan florist. Bagi petani yang menjual hasil panennya kepada langganan ini, merasakan bahwa keuntungan yang diperoleh lebih besar dibandingkan dengan menjual hasil panen langsung ke pasar atau melalui tengkulak, karena jika dijual ke pendekor atau florist, harganya akan jauh lebih tinggi dan cenderung stabil dibandingkan dengan pasar. Selain itu, jika harga turun, sebagian petani menyiasatinya dengan melakukan pembibitan sendiri untuk meminimalisir biaya produksi dan tentunya bertujuan untuk mendapatkan keuntungan walau sedikit. Cara lain yang dapat dilakukan guna memperoleh keuntungan yang lumayan, beberapa petani melakukan alternatif penjualan. Jika harga pasar sedang baik, mereka akan menjual krisan grade A langsung ke pasar dan krisan grade $\mathrm{B}$ dijual melalui tengkulak atau pedagang, sementara jika harga sedang turun, mereka akan menjual sebagian krisan ke florist dan pendekor dan sisanya dijual langsung ke pasar atau melalui tengkulak dan pedagang.

Pada umumnya, banyak petani yang memilih untuk menitipkan hasil panennya melalui tengkulak dan pegadang. Sebagian besar petani yang menitipkan hasil panennya kepada tengkulak dan pedagang tidak akan langsung memperoleh uang saat itu juga. Biasanya pembayarannya akan dilakukan setelah masa panen selesai. Dalam menitipkan hasil panennya, petani tidak hanya bekerjasama dengan satu tengkulak atau pedagang saja, biasanya petani akan memilih tengkulak atau pedagang yang berani membeli dengan harga yang lebih tinggi terutama saat harga sedang baik. Selain itu, ada juga beberapa petani yang bekerjasama dengan florist dan pendekor, namun kerjasama ini tidak mengharuskan petani untuk selalu memenuhi permintaan mereka. Saat harga sedang baik, petani memilih untuk menjual hasil panennya langsung ke pasar dibandingkan dengan menjualnya kepada florist dan pendekor, hal ini dikarenakan harga yang dibayarkan oleh mereka biasanya cenderung stabil (saat harga naik dan turun biasanya dibeli dengan harga sama). Itu sebabnya petani tidak terlalu berorientasi pada fokus jangka panjang, justru banyak petani yang lebih memilih untuk menjual langsung hasil panennya ke pasar tanpa perantara, dengan alasan mereka akan lebih cepat memperoleh uang hasil penjualan untuk memenuhi kebutuhan sehari-hari.

Berdasarkan nilai rata-ratanya, sortasi memiliki nilai 1,53 . Hal tersebut menunjukkan bahwa belum semua petani melakukan sortasi jika dilihat dari beberapa indikatornya, seperti tersedianya tempat untuk sortasi. Petani biasanya akan melakukan sortasi atau pemilahan hasil bunga potong krisan yang baik dari yang rusak atau cacat langsung di lahan, petani tidak menyediakan tempat khusus dengan alasan proses sortasi bisa lebih cepat dan tidak membutuhkan banyak biaya untuk membangun ruangan khusus untuk sortasi. Selain dari itu, hanya ada 42 dari 100 petani yang menyampaikan bahwa mereka mengikuti pelatihan dan petunjuk dari penyuluh pertanian dalam melakukan kegiatan budidaya hingga pasca panen bunga potong krisan, hal ini dikarenakan pelatihan dan penyuluhan hanya diberikan kepada petani yang tergabung dalam anggota kelompok tani, sementara yang belum tergabung biasanya 
akan belajar cara budidaya hingga pasca panen secara mandiri atau bertanya kepada petani yang sudah mengikuti pelatihan dan penyuluhan tersebut. Dalam melakukan kegiatan sortasi, ada 42 dari 100 petani yang telah memperkerjakan karyawan yang telah menguasai teknik sortasi. Biasanya petani memperkerjakan karyawan hanya saat dibutuhkan saja ketika petani merasa tidak bisa menanganinya seorang diri, sehingga bisa dikatakan bahwakaryawan yang dipekerjakan bukanlah karyawan tetap.

Berdasarkan nilai rata-ratanya, pengkelasan memiliki nilai 2,82. Hal ini menunjukkan bahwa dalam melakukan pengkelasan, masih ada petani yang melakukan dan tidak melakukan. Petani biasanya melakukan kegiatan pengkelasan atau pemilahan hasil bunga potong berdasarkan gradenya didasarkan pada orientasi pasarnya, misalnya untuk memenuhi permintaan tengkulak dan pedagang yang kemudian dijual kembali kepada florist besar, petani akan menyediakan bunga potong krisan grade $\mathrm{A}$ dengan panjang tangkai sekitar 70-100cm, kuntum bunga sehat dan tidak terserang penyakit, sementara untuk memenuhi permintaan pendekor dan florist kecil, petani akan menyediakan krisan grade $\mathrm{B}$ dengan panjang tangkai kurang dari $70 \mathrm{~cm}$ dan pada kuntum bunga terdapat sedikit bercak. Namun, kadang dalam melakukan tahap pengkelasan, ada pula petani yang tidak melakukan pemilahan grade, hal ini dikarenakan petani melihat bahwa semua bunga potong yang dihasilkan dalam satu petak lahan sudah seragam dan bisa dikategorikan ke dalam grade yang sama, sehinggapetani biasanya akan langsung melakukan tahap selanjutnya yaitu pembungkusan.

Berdasarkan nilai rata-ratanya, pembungkusan memiliki nilai 2,06. Hal ini menunjukkan bahwa belum semua petani melakukan pembungkusan dengan baik. Misalnya saja dalam hal menggunakan pembungkus yang sesuai standar, berdasarkan petunjuk dari penyuluh pertanian menurut petani yang tergabung dalam kelompok tani, disarankan untuk menggunakan pembungkus berupa kertas HVS atau kertas putih bersih untuk semua jenis bunga potong krisan, akan tetapi petani merasakan hal itu cukup berat karena akan membutuhkan biaya yang besar untuk membeli pembungkus tersebut, sehingga petani menyiasati dengan menggunakan koran bekas untuk membungkus bunga potong krisan jenis spray, sementara untuk bunga potong krisan dengan jenis standard masingmasing kelopak bunganya "dicontongi" terlebih dahulu menggunakan kertas HVS, baru kemudian dibungkus dengan menggunakan koran bekas. Hal ini dikarenakan bunga potong krisan jenis standard harus dijaga kelopak bunganya terutama saat pengangkutan, dimana bunga potong krisan jenis ini hanya memiliki satu kuntum bunga per tangkai.

\section{Pengujian Hipotesis}

Uji statistik hasil pengolahan SEM dilakukan dengan melihat nilai probabilitas dan CR masing-masing variabel (Luviana, 2013). Hasilnya dapat dilihat pada Tabel 4.

\section{Uji Hipotesis 1}

Berdasarkan hasil pengolahan data terhadap hipotesis 1, diperoleh nilai critical ratio (CR) berturut-turut sebesar -0,607, -0,513 dan 2,145 dengan probabilitas masing-masing $0,544,0,608$ dan 0,032 , sementara nilai standardized koefisiennya berturut-turut $-0,079,-0,066$ dan $-0,289$. Hasil tersebut menunjukkan bahwa dua dari tiga faktor determinan orientasi pasar tidak dapat diterima karena nilai CR < 1,96 dan probabilitasnya $>$ 0,05 (Luviana, 2013). Hal ini bertolak belakang dengan penelitian yang dilakukan oleh Jaworski \& Kohli (1993) yang mengungkapkan bahwa ada tiga faktor determinan orientasi pasar dilihat dari karakteristik individu antara lain: usia, pendidikan dan jenis kelamin. Dari 
hasil analisis SEM, diketahui bahwa hanya jenis kelamin yang berhubungandengan orientasi pasar petani, sementara usia dan pendidikan tidak berhubungan sama sekali.

Menurut Jaworski \& Kohli (1993), usia mendukung kemampuan seseorang dalam pengelolaan usaha karena dapat mempengaruhi daya kreativitas seseorang, semakin tua usianya, semakin matang daya kreativitasnya. Dalam penelitian ini, responden sebagian besar berusia 40 tahun ke atas dan sudah seharusnya memiliki banyak pengalaman serta memiliki daya kreativitas yang matang. Namun, hal yang perlu diingat, kreativitas tanpa adanya wadah untuk mengasahnya dan menuangkannya melalui keterampilan, tidak akan dapat berkembang. Itulah yang terjadi pada petani di Desa Kenteng, tidak semuapetani mengikuti pelatihan rutin dari penyuluh dikarenakan tidak semua petani tergabung dalam kelompok tani, sehingga mereka hanya melakukan sebisanya sajadalam menerapkan orientasi pasarnya. Selain itu, bagi petani usia 40 tahun ke atas, usaha ini hanya dilakukan sebagai alternatif pekerjaan dikarenakan diusia mereka, mereka sudah tidak dapat bekerja di tempat lain sehingga dalam menjalankan usaha ini, mereka cenderung melakukannya sebisanya dan terkadang mengikuti apa yang petani lainnya lakukan. Sementara pendidikan, dalam banyak kasus sangat mempengaruhi stock of knowledge seseorang sehingga mampu menggerakkan inovasi usaha. Pendidikan yang sesuai dengan bidang yang digelutinya merupakan dasar yang sangat baik untuk pengembangan usahanya (Hisrich \& Peters, 1992 dalam Priyanto, 2005). Namun yang perlu diingat adalah tingkat pendidikan tidak selamanya linier dengan kemampuan seseorang karena juga sangat tergantung proses pembelajaran yang terjadi pada saat memperoleh pendidikan tersebut. Pada penelitian ini, petani sebagian besar hanya menempuh pendidikan setingkat SD saja dan bisa dikatakan bahwa pendidikan tersebut belum dapat memberikan pengetahuan dan keterampilan yang cukup dalam mengasah kemampuan petani untuk berinovasi dalam usahanya. Ini terlihat dari cara berpikir dan sikap petani dalam hal memproduksi bunga potong krisan. Petani cenderung untuk memilih menanam krisan yang sudah digemari dipasaran dibandingkan dengan mencoba menanam krisan varietas baru dengan alasan takut mengalami kerugian jika hasil panennya tidak laku terjual di pasar. Hal ini yang mendasari sehingga usia dan pendidikan tidak berperan

Tabel 4 Nilai Terukur Regresi

Regression Weights: (Group number 1 - Default model)

\begin{tabular}{|c|c|c|c|c|c|c|c|}
\hline & & & Estimate & S.E. & C.R. & $\mathrm{P}$ & Label \\
\hline OrientasiPasar & $\begin{array}{l}<--- \\
\end{array}$ & Pendidikan &,- 027 & ,053 &,- 513 & ,608 & par_7 \\
\hline OrientasiPasar & $<---$ & Usia &,- 003 & ,005 &,- 607 &, 544 & par_8 \\
\hline OrientasiPasar & $<---$ & JenisKelamin &,- 374 & , 174 & $-2,145$ & ,032 & par_9 \\
\hline PascaPanen & $<---$ & OrientasiPasar & ,927 & 289 & 3,214 & 001 & par_6 \\
\hline OrPel & $<---$ & OrientasiPasar & 1,000 & & & & \\
\hline OrPes & $<---$ & OrientasiPasar & 1,154 & ,344 & 3,356 & $* * *$ & par_1 \\
\hline OrFok & $<---$ & OrientasiPasar & 1,156 & ,385 & 3,000 & ,003 & par_2 \\
\hline OrPro & $<---$ & OrientasiPasar &, 451 & 200 & 2,252 & ,024 & par_3 \\
\hline Sort & $<---$ & PascaPanen & 1,000 & & & & \\
\hline Peng & $<---$ & PascaPanen & ,729 & , 156 & 4,679 & $* * *$ & par_4 \\
\hline Pemb & $<---$ & PascaPanen & 1,280 & ,252 & 5,087 & $* * *$ & par_5 \\
\hline
\end{tabular}

Sumber: Analisis Data Primer, 2016 
sebagai faktor determinan orientasi pasar pada petani di Desa Kenteng.

Pada penelitian ini, hanya jenis kelamin yang menjadi faktor determinan dari orientasi pasar dikarenakan jenis kelamin sangat mempengaruhi strategi usaha dan tingkah laku (Powell \& Ansic, 1997 dalamMunoz \& Saran 2012). Dalam penelitian ini, peran jenis kelamin sebagai faktor determinan orientasi pasar petani nilai CR nya negatif dan probabilitasnya signifikan $<0,05$, ini berarti petani perempuan memiliki orientasi pasar yang lebih baik dibandingkan dengan petani laki-laki. Hal ini dikarenakan petani perempuan mengandalkan jaringan sosialnya dalam menjalankan usahanya (Brush, 1992 dalamMunoz \& Saran, 2012) seperti menjalin relasi dengan banyak tengkulak, pedagang dan juga pendekor. Salah satu dari 9 petani perempuan bahkan menjual hasil panennya melalui media sosial yaitu facebook dan dalam menjual hasil panennya, beliau akan lebih mengutamakan pesanan melalui media sosial tersebut, kemudian sisanya dijual melalui tengkulak, pedagang dan ke pasar langsung. Hal ini juga diperkuat dengan teori yang disampaikan oleh Riger \& Gilliga, 1980
dalamDavis et al., 2010, perempuan dan lakilaki berbeda dalam orientasi terhadap relasi. Perempuan lebih peduli pada hubungan antar pribadi dengan pelanggan dibandingkan lakilaki (Cartwright \& Gale, 1995dalamDavis et al., 2010). Perempuan menunjukkan perhatian yang lebih besar dalam menjalin relasi dari aspek pemasaran dan penjualan. Hal ini dapat bermanfaat untuk mengembangkan orientasi pasar (Narver \& Slater, 1990 dalamDavis et al., 2010). Pada petani di Desa Kenteng, sebagian besar yang berperan dalam pemasaran dan penjualan adalah perempuan, jika saat panen tiba dan waktunya untuk berjualan, petani laki-laki akan menyerahkan hasil panen krisannya kepada istrinya untuk dijual ke pasar atau dijual melalui tengkulak dan pedagang, sehingga bisa dikatakan bahwa perempuan yang berperan besar dalam menjalin relasi dengan pelanggan. Alasan inilah yang menyebabkan jenis kelamin berperan sebagai faktor determinan orientasi pasar petani di Desa Kenteng.

Selain daripada itu, peneliti juga berusaha mencari alasan petani dalam menerapkan orientasi pasarnya. Peneliti menemukan beberapa alasan antara lain: sesuai dengan yang

Tabel 5 Nilai Terukur Regresi Terstandar

\begin{tabular}{|c|c|c|c|}
\hline & & & Estimate \\
\hline Orientasi Pasar & $<---$ & Pendidikan &,- 066 \\
\hline Orientasi Pasar & $<---$ & Usia &,- 079 \\
\hline Orientasi Pasar & $<---$ & Jenis Kelamin &,- 289 \\
\hline Pasca Panen & $<---$ & Orientasi Pasar & ,838 \\
\hline OrPel & $<---$ & Orientasi Pasar & ,603 \\
\hline OrPes & $<---$ & Orientasi Pasar &, 512 \\
\hline OrFok & $<---$ & Orientasi Pasar & ,449 \\
\hline OrPro & $<---$ & Orientasi Pasar & ,281 \\
\hline Sort & $<---$ & Pasca Panen & ,688 \\
\hline Peng & $<---$ & Pasca Panen &, 573 \\
\hline Pemb & $<---$ & Pasca Panen & ,752 \\
\hline
\end{tabular}


disampaikan oleh Narver \& Slater (1990), setiap pengusaha akan selalu berusaha memenuhi permintaan dan keinginan pelanggan. Pada dasarnya, pasar dan konsumen menginginkan bunga krisan dengan standar mutu yang lebih baik dari yang telah dihasilkan oleh petani, serta permintaan pasar dan konsumen yang terbesar adalah krisan sebagai bunga potong tunggal ukuran besar dan spray (Cakrabarti \& Sarker, 2011 dalam Pratomo \& Andri, 2013). Dalam hal ini, pasar dan konsumen yang dimaksud adalah tengkulak, pedagang, florist dan pendekor. Selain itu, adanya tuntutan untuk memenuhi kepuasan konsumen akan kualitas bunga potong krisan yang dibelinya juga turut menjadi alasan dari kepemilikan orientasi pasar oleh petani (Holilah, 2005). Menurut Hutchinson et al (2003) dalam Riyanto (2010), untuk memberikan kepuasan konsumen dan memenuhi permintaan pasar salah satu usaha yang dapat dilakukan yaitu dengan meningkatkan hasil panen dan tetap mempertahankan kualitasnya.Kemudian, disampaikan pula oleh Kementerian Pertanian Badan Penyuluhan dan Pengembangan Sumber Daya Manusia Pertanian (2016), bahwa konsumen menuntut kualitas yang baik, bukan hanya kuantitas, sehingga jika panen banyak tetapi kualitasnya rendah, maka tidak akan terjual semua, sehingga hal ini membuat petani selalu mengutamakan kualitasnya untuk memenuhi kebutuhan dan kepuasan konsumen. Dari beberapa literatur tersebut, peneliti menyimpulkan bahwa alasan dari kepemilikan orientasi pasar oleh petani dikarenakan adanya tuntutan dari pasar (tengkulak, pedagang dan florist) dan konsumen (pendekor).

\section{Uji Hipotesis 2}

Berdasarkan hasil analisis pengolahan data terhadap hipotesis 2, diperoleh nilai critical ratio $(\mathrm{CR})$ sebesar 3,214 > 1,96 dengan probabilitas $0,001<0,05$, sementara nilai standardized koefisiennya sebesar 0,838. Hasil tersebut menunjukkan bahwa hipotesis yang diajukan dapat diterima, yang dapat dilihat dari nilai CR $>1,96$ dan probabilitasnya $<0,05$ (Luviana, 2013), sehingga dapat disimpulkan bahwa orientasi pasar berpengaruh positif terhadap penanganan pasca panen bunga potong krisan dengan pengaruhnya sebesar 0,838 atau $83,8 \%$. Hal ini sejalan dengan penelitian yang dilakukan oleh Narver $\&$ Slater (1990) yang mengatakan bahwa penanganan pasca panen yang dilakukan pengusaha bunga potong krisan selalu didasarkan pada keinginan dan kebutuhan konsumen dan hal inilah yang dikenal dengan orientasi pasar. Perlakuan pasca panen ini dilakukan tidak hanya untuk memenuhi kebutuhan pelanggan, melainkan melalui perlakuan ini, petani bisa mendapatkan keuntungan yang lebih besar dibandingkan menjual hasil panen tanpa melakukan kegiatan pasca panen. Selain memperoleh keuntungan, adanya keinginan petani untuk dapat memenuhi kebutuhan pelanggan dilakukan dengan cara menghasilkan bunga potong krisan yang berpenampilan baik, menarik, sehat dan memiliki shelflife (umur simpan) serta vaselive (umur kesegaran) yang cukup optimal (Fernando, 2015), sehingga hasil panennya dapat lebih bersaing dibandingkan dengan petani yang tidak melakukan kegiatan pasca panen. Hal ini disampaikan oleh Narver \& Slater (1990), bahwa pengusaha yang berorientasi pada pesaing akan melihat pangsa pasarnya serta berusaha untuk memenuhi kebutuhannya.Kegiatan pasca panen ini dilakukan pula untuk menarik pelanggan agar bisa berkelanjutan dalam membeli bunga potong yang dihasilkan oleh petani, ini sesuai dengan pendapat Narver \& Slater (1990), hubungan dengan pelanggan jangka panjang ini hanya dapat terwujud jika pengusaha mampu memuaskan pelanggan dengan cara yang lebih unggul dibanding pesaing, yang pada umumnya 
dapat ditempuh dengan kualitas, pelayanan, inovasi, keunikan produk dan harga yang lebih bersaing. Selain itu, Holilah (2005) juga menyampaikan bahwa dilihat dari aspek teknis, penanganan pasca panen yang terdiri dari sortasi, pengemasan dan pemeliharaan yang dilakukan dengan baik akan menghasilkan bunga potong yang dapat memberikan kepuasan terhadap konsumennya. Dari hal ini, peneliti menyimpulkan bahwa adanya keinginan dan kebutuhan pelanggan terhadap bunga potong krisan menjadi pedoman bagi petani dalam melakukan perlakuan pasca panen sehingga petani dapat memberikan kepuasan kepada pelanggan.

\section{KESIMPULAN}

1. Petani krisan di Desa Kenteng telah menerapkan orientasi pasar. Pemenuhan kebutuhan pelanggan akan bunga potong krisan yang berkualitas dan menarik menjadi orientasi yang paling banyak diterapkan oleh petani. Di sisi lain, petani juga melakukan kegiatan pasca panen untuk menghasilkan bunga potong krisan yang lebih baik dari pesaingnya sehingga petani bisa mendapatkan keuntungan yang lebih besar dibandingkan petani yang mengesampingkan kegiatan pasca panen. Sementara orientasi fokus jangka panjang tidak begitu diterapkan karena petani memiliki cara tersendiri dalam memasarkan hasil panennya seperti menggunakan alternatif penjualan.

2. Berdasarkan hasil analisis SEM, faktor determinan orientasi pasar dilihat dari karakteristik individu petani (usia, pendidikan dan jenis kelamin) yang telah dikemukakan dalam penelitian ini, hanya jenis kelamin yang dapat dikatakan sebagai faktor determinan orientasi pasar petani di Desa Kenteng. Namun, selain dari jenis kelamin, peneliti juga menemukan dari beberapa kajian literatur bahwa kepemilikan orientasi pasar oleh petani di Desa Kenteng ini berasal dari tuntutan pasar (tengkulak, pedagang dan florist) dan konsumen (pendekor).

3. Berdasarkan hasil analisis SEM, orientasi pasar terbukti memberi pengaruh positif terhadap penanganan pasca panen yang dilakukan oleh petani bunga potong krisan di Desa Kenteng, sementara sisanya dipengaruhi oleh faktor lain yang tidak dibahas dalam penelitian ini. Adanya tuntutan pelanggan terhadap bunga potong krisan yang berpenampilan baik, menarik, sehat dan bebas dari serangan hama penyakit membuat petani lebih memperhatikan kegiatan pasca panen yang meliputi sortasi, pengkelasan dan pembungkusan sehingga bunga potong krisan yang dihasilkan mampu bersaing dengan hasil bunga potong krisan petani lainnya terutama dari segi harga dan petani juga mampu memberikan kepuasan kepada pelanggannya yang kemudian berujung pada keberlanjutan pelanggan dalam membeli bunga potong krisan kepada petani.

\section{DAFTAR PUSTAKA}

Arisanti, D., \& Setiari, N. 2012. Pengaruh Pemberian Vitamin C (asam askorbat) terhadap Kesegaran Bunga Krisan (Chrysanthemum sp) pada Kawasan Sentra Penghasil di Desa Ngasem, Kecamatan Jetis, Bandungan, Jawa Tengah. Buletin Anatomi dan Fisiologi, 20(1), 37-46.

Bungin, H.M. B. 2011. Penelitian Kualitatif. Jakarta: Kencana.

Darmasetiawan \& Wicaksono. 2012. Pengaruh Faktor Internal Petani terhadap Peningkatan Mutu Tembakau di Desa Pacekelan Kecamatan Purworejo Kabupaten Purworejo. Surya Agritama, 1(1), 48-58. 
Davis et al,. 2010. The Influence of CEO Gender on Market Orientation and Performance in Service Small and Medium-Sized Service Business. Small Business Management, 48(4), 475-496.

Fernando, A. R. 2015. Pengaruh Penerapan Standar Operasional Prosedur (SOP) terhadap Produktivitas Bunga Krisan. Skripsi. Yogyakarta: Universitas Pembangunan Nasional "Veteran".

Holilah, L. 2005. Analisis Kelayakan Usaha Bunga Potong pada Pusat Promosi dan Pemasaran Hasil Pertanian dan Hasil Hutan Rawabelong. Skripsi. Jakarta: Universitas Islam Negeri Syarif Hidayatullah.

Jaworski, B.J.,\& Kohli, A.K. 1993. Market Orientation: Antecedents and Consequences. Journal of Marketing, 57, 53-70.

Kementerian Pertanian Badan Penyuluhan dan Pengembangan Sumber Daya Manusia Pertanian. 2016. Wirausaha Petani. http:/ /cybex.pertanian.go.id/ materilokalita/ detail/9393/wirausaha-petani (diakses tanggal 28 Mei 2016 pukul 20:58).

Luviana, S. 2013. Persepsi Produk Makanan Organik dan Minat Beli Konsumen. Skripsi. Surakarta: Universitas Sebelas Maret.

Munoz \& Saran. 2012. Market Orientation, Innovation, and Dynamism from an Ownership and Gender Approach: Evidence from Mexico. Management and Makerting Research, 5(2), 1-17.

Narver, J. C., \& Slater S. F. 1990. The Effect of a Market Orientation Business Profitability. Journal of Marketing, 2035.

Nazir, M. 1985. Metode Penelitian. Jakarta: Ghalia Indonesia.
Pratomo, A. G.,\& Andri, K. B. 2013. Aspek Sosial Ekonomi dan Potensi Agribisnis Bunga Krisan di Kabupaten Pasuruan Jawa Timur. Hort. Indonesia, 4(2), 7076.

Priyanto, S. H. 2005. Hubungan Orientasi Pasar dan Efisiensi Usahatani. AGRIC,18(1), 19-40.

Purwasari, M. M. N., \& Suprapto, B. 2014. Pengaruh Orientasi Pasar terhadap Kinerja Cafe di Yogyakarta. Tesis. Yogyakarta: Universitas Atma Jaya Yogyakarta.

Riyanto. 2010. Pengawetan Bunga Potong Sedap Malam dengan Larutan Perak Nitrat. Agri Sains, 1(2), 46-53.

Rukmana, R., \& Mulyana, A. E. 1997. Krisan. Yogyakarta: Kanisius.

Sarjono, H., \& Julianita, W. 2015. Structural Equation Modeling (SEM). Jakarta: Salemba Empat.

Sekaran, U. 2006. Research Methods for Business. Jakarta: Salemba Empat.

Supriyadi, A. 2012. Analisis Pengaruh Orientasi Pasar, Kreativitas dan Inovasi Produk terhadap Kinerja Pemasaran untuk Meningkatkan Keunggulan Bersaing Berkelanjutan (Studi Kasus pada Kerajinan Logam Cepogo, Kecematan Cepogo, Kabupaten Boyolali). Skrispi. Surakarta: Universitas Sebelas Maret.

Umar, H. 2002. Metode Riset Bisnis: Jakarta: Gramedia Pustaka Utama. 2005. Riset SDM dalam

Organisasi. Jakarta: Gramedia Pustaka Utama. 